\title{
Titanium dioxide nanoparticles induce the expression of early and late receptors for adhesion molecules on monocytes
}

\author{
Cristhiam Rueda-Romero 1,2, Guillermina Hernández-Pérez ², Pilar Ramos-Godínez³ Inés Vázquez-López , \\ Raúl Omar Quintana-Belmares ${ }^{1}$, Elizabeth Huerta-García ${ }^{4}$, Ewa Stepien ${ }^{5}$, Rebeca López-Marure ${ }^{4}$, \\ Angélica Montiel-Dávalos ${ }^{1}$ and Ernesto Alfaro-Moreno ${ }^{1,6^{*}}$
}

\begin{abstract}
Background: There is growing evidence that exposure to titanium dioxide nanoparticles $\left(\mathrm{TiO}_{2} \mathrm{NPs}\right)$ could be harmful. Previously, we have shown that $\mathrm{TiO}_{2} \mathrm{NPs}$ induces endothelial cell dysfunction and damage in glial cells. Considering that inhaled particles can induce systemic effects and the evidence that nanoparticles may translocate out of the lungs, we evaluated whether different types of $\mathrm{TiO}_{2} \mathrm{NPs}$ can induce the expression of receptors for adhesion molecules on monocytes (U937 cell line). We evaluated the role of reactive oxygen spices (ROS) on these effects.

Methods: The expression of receptors for early (sLe $\mathrm{e}^{\mathrm{x}}$ and PSGL-1) and late (LFA-1, VLA-4 and aVB3) adhesion molecules was evaluated in U937 cells on a time course (3-24 h) using a wide range of concentrations (0.001-100 $\mathrm{gg} / \mathrm{mL}$ ) of three types of $\mathrm{TiO}_{2} \mathrm{NPs}(<25 \mathrm{~nm}$ anatase, $50 \mathrm{~nm}$ anatase-rutile or $<100 \mathrm{~nm}$ anatase). Cells exposed to TNFa were considered positive controls, and unexposed cells, negative controls. In some experiments we added $10 \mu$ molar of $\mathrm{N}$-acetylcysteine (NAC) to evaluate the role of ROS.

Results: All tested particles, starting at a concentration of $0.03 \mu \mathrm{g} / \mathrm{mL}$, induced the expression of receptors for early and late adhesion molecules. The largest increases were induced by the different molecules after $3 \mathrm{~h}$ of exposure for sLe ${ }^{x}$ and PSGL-1 (up to 3-fold of the positive controls) and after $18 \mathrm{~h}$ of exposure for LFA-1, VLA-4 and aVB3 (up to 2. 5 -fold of the positive controls). Oxidative stress was observed as early as 10 min after exposure, but the maximum peak was found after $4 \mathrm{~h}$ of exposure. Adhesion of exposed or unexposed monocytes to unexposed or exposed endothelial cells was tested, and we observed that monocytes cells adhere in similar amounts to endothelial cells if one of the two cell types, or both were exposed. When NAC was added, the expression of the receptors was inhibited.

Conclusions: These results show that small concentrations of particles may activate monocytes that attach to endothelial cells. These results suggest that distal effects can be induced by small amounts of particles that may translocate from the lungs. ROS play a central role in the induction of the expression of these receptors.
\end{abstract}

Keywords: Titanium dioxide nanoparticles, Monocyte, Endothelial cell, Adhesion molecules, sLex, PSGL-1, LFA-1, VLA-4, aVB3

\footnotetext{
* Correspondence: ernesto.alfaro-moreno@swetox.se

${ }^{1}$ Environmental Toxicology Laboratory, Subdirección de Investigación Básica,

Instituto Nacional de Cancerología, Ciudad de México, México

${ }^{6}$ Swedish Toxicology Sciences Research Center (Swetox), Forskargatan 20,

15136 Södertälje, Sweden

Full list of author information is available at the end of the article
} 


\section{Background}

Titanium dioxide particles $\left(\mathrm{TiO}_{2}\right)$ have been considered as nontoxic mineral particles and traditionally used in the fields of cosmetics, food, and drugs. They were even used as "dust negative control" in many in vitro and in vivo toxicological investigations for many years $[1,2]$. Titanium dioxide nanoparticles $\left(\mathrm{TiO}_{2} \mathrm{NPs}\right)$ consists of three crystals forms, including anatase, rutile, and brookite [3]. $\mathrm{TiO}_{2}$ NPs have been widely used in many products, such as toothpastes, sunscreens, cosmetics, food products, pharmaceuticals, and nanomedical reagents [4]. However, research evidence suggests that $\mathrm{TiO}_{2} \mathrm{NPs}$ may possess higher toxicity potential than their bulk materials [4-6]. Several investigations found that $\mathrm{TiO}_{2} \mathrm{NPs}$ can penetrate basic biological structures, which may, in turn, disrupt their normal function $[1,6,7]$. Also recent research evidence shows that $\mathrm{TiO}_{2}$ NPs may induce cellular toxicity effects in cardiac tissue [8]. The toxic effects of $\mathrm{TiO}_{2}$ NPs were also observed in cells of the circulatory system. Previous studies found that erythrocytes treated with $\mathrm{TiO}_{2}$ NPs underwent abnormal sedimentation, hemagglutination, and hemolysis, which were totally different from those treated with fine particles of $\mathrm{TiO}_{2}$ [2]. Size, effective cellular dose, biokinetics, physicochemical and surface properties could be responsible for these differences [9].

Exposure to nanoparticles has been linked to local and systemic effects such as lung inflammation, enhanced thrombotic potential and systemic endothelial dysfunction [10]. Increasing amounts of evidence show that $\mathrm{TiO}_{2}$ NPs may induce airway irritation, lung inflammation, hepatic and renal effects, proinflammatory effects and systemic microvascular dysfunction [11]. Recently, the International Agency for Research on Cancer (IARC) classified $\mathrm{TiO}_{2}$ as a $2 \mathrm{~B}$ carcinogen [12]. The mechanism by which $\mathrm{TiO}_{2} \mathrm{NPs}$ induces the above effects is not well understood. Regarding how inhaled nanoparticles or ultrafine particles can induce systemic effects, the hypothesis of particle translocation from the lungs into the bloodstream could explain how an inhaled particle could be linked to a systemic adverse outcome [13-15]. Considering that the alveolar-capillary barrier does not allow large quantities of particles to translocate, it is reasonable to assume that only a tiny fraction of inhaled particles may translocate. Therefore exploring the cellular effects of nanoparticles at very low concentrations is necessary $[16,17]$.

Several studies have shown in vivo and in vitro that inhaled particles may induce endothelial activation and dysfunction. In vitro evidence indicates that particle concentrations above $1 \mu \mathrm{g} / \mathrm{cm}^{2}$ are needed to induce endothelial dysfunction [18], but it is not clear if these particle concentrations are sufficient for translocation to the endothelium in vivo. Few in vivo studies showed deleterious effect of $\mathrm{TiO}_{2}$ on vascular cells, initiation of endothelial cell dysfunction and damage. Pulmonary exposure (instillation) to high doses of $\mathrm{TiO}_{2} \mathrm{NPs}$ caused systemic inflammation, dyslipidemia and enhanced atherosclerotic plaque progression in ApoE-knockout mice $[19,20]$. However, some contradictory data are also available, showing the modest effect on plaque progression in the same animal model [21]. At cellular level, endothelial dysfunction is associated with local elevation of pro-inflammatory mediators (cytokines, chemoatractants and cell adhesion molecules), which can lead to atherosclerosis, but the role of the local nanoparticle exposure on systemic processes (atherosclerosis) is still poorly understood [8]. Secreted inflammatory factors have been proposed as possible mediators of local and systemic inducers of endothelial dysfunction [22]. Nevertheless, there is no evidence that monocytes may be activated by very small amount of particles. An alternative hypothesis involves the production of circulating microvesicles that may transfer nanoparticles within the bloodstream to reach distant target cells [22].

The monocyte-endothelial cell interaction is mediated by several molecules playing different roles such as capture/tethering, rolling, activation, adhesion, diapedesis, traversing the basal lamina and migration [23]. Previously, we demonstrated that $\mathrm{TiO}_{2} \mathrm{NPs}$ and urban particles are capable of inducing the expression of $\mathrm{E}$ and $\mathrm{P}$ selectins and ICAM-1, VCAM-1 and PECAM- 1 in endothelial cells exposed to concentrations of $5 \mu \mathrm{g} / \mathrm{cm}^{2}$ [17]. Monocytes express surface molecules that are ligands for adhesion molecules, including $\mathrm{sLe}^{\mathrm{x}}$ (E-selectin ligand) [24], PSGL-1 (P-selectin ligand) [23], LFA-1 (ICAM-1 ligand) [25], VLA-4 (VCAM-1 ligand) [26] and $\alpha V \beta 3$ (PECAM-1 ligand) [27], among others. In the present study, we evaluated whether $\mathrm{TiO}_{2}$ NPs activates monocytes and induces the expression of sLe ${ }^{\mathrm{x}}$, PSGL-1, LFA-1, VLA- 4 and $\alpha \mathrm{V} \beta 3$, promoting the adhesion of monocytes to endothelial cells, even if these endothelial cells were not challenged with particles.

\section{Results}

All $\mathrm{TiO}_{2}$ NPs samples were negative for the presence of endotoxin. The $\mathrm{X}-\mathrm{RF}$ analysis did not show the presence of any other elements besides oxygen and titanium. The size and $\zeta$-potential for the $<50 \mathrm{~nm} \mathrm{TiO}_{2} \mathrm{NPs}$ have been previously reported [17]. For the $<25 \mathrm{~nm} \mathrm{TiO}_{2} \mathrm{NPs}$ the average size was $19 \mathrm{~nm}$ with a $\zeta$-potential of $-12 \mathrm{mV}$. The $<100 \mathrm{~nm} \mathrm{TiO}_{2}$ NPs average size was $80 \mathrm{~nm}$ with a $\zeta$-potential of $-8.9 \mathrm{mV}$.

The three different sizes of $\mathrm{TiO}_{2}$ NPs induced very similar results. To keep the results as simple as possible, we will describe the general results for the $<50 \mathrm{~nm}$ anatase-rutile, the effects of which on HUVECs we have previously characterized [17]. The results for $<25 \mathrm{~nm}$ 
anatase and $<100 \mathrm{~nm}$ anatase-rutile are presented as Additional file 1 .

\section{Expression of sLe $e^{x}$ and PSGL-1}

sLe $^{\mathrm{x}}$ and PSGL-1 were induced in U937 cells exposed to $\mathrm{TiO}_{2}$ NPs at all times tested ( $p<0.05$ vs negative control). The largest induction was observed after $3 \mathrm{~h}$ of exposure (Fig. $1 \mathrm{a}-\mathrm{c}$ ). Originally, we tested concentrations from $0.3 \mu \mathrm{g} / \mathrm{mL}$, but due to the absence of negative results with lower concentrations of $\mathrm{TiO}_{2} \mathrm{NPs}$, we decided to test even lower concentrations. When concentrations from 0.001 to $0.030 \mu \mathrm{g} / \mathrm{mL}$ were included, we observed negative results at concentrations between 0.001 and $0.010 \mu \mathrm{g} / \mathrm{mL}$; however, from $0.030 \mu \mathrm{g} / \mathrm{mL}$, we observed an induction as strong as the induction induced by the positive controls ( $p<0.05$ vs negative control) (Fig. 1 a-d).

\section{Expression of LFA-1, VLA-4 and $\alpha \mathrm{V} \beta 3$}

LFA-1, VLA-4 and $\alpha \mathrm{V} \beta 3$ expression was induced by $\mathrm{TiO}_{2} \mathrm{NPs}$ at all tested times. The largest amount of expression was observed at $18 \mathrm{~h}$ after exposure (Fig. $2 \mathrm{a}-\mathrm{f}$ ), but levels of expression similar to those of the positive

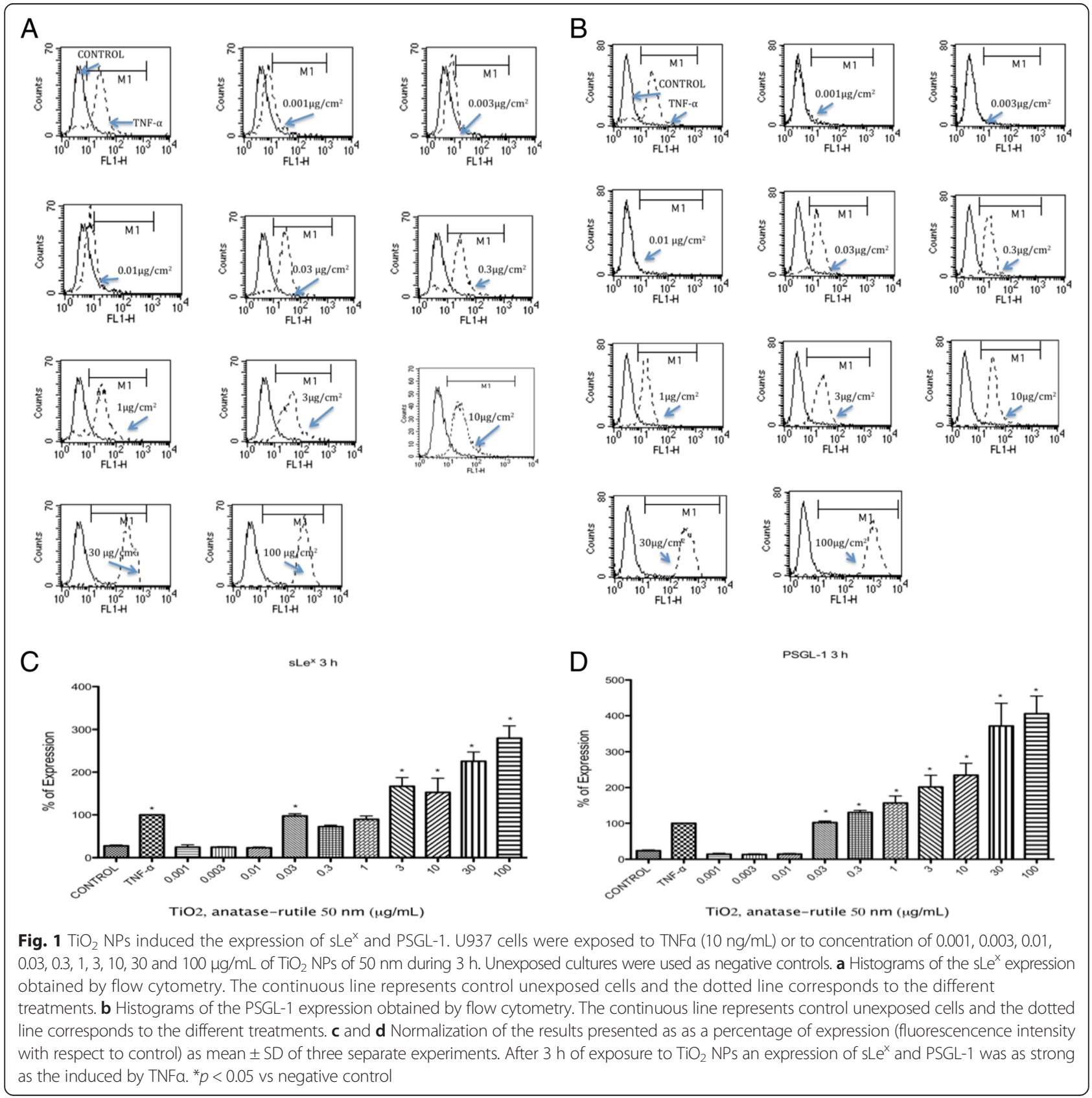




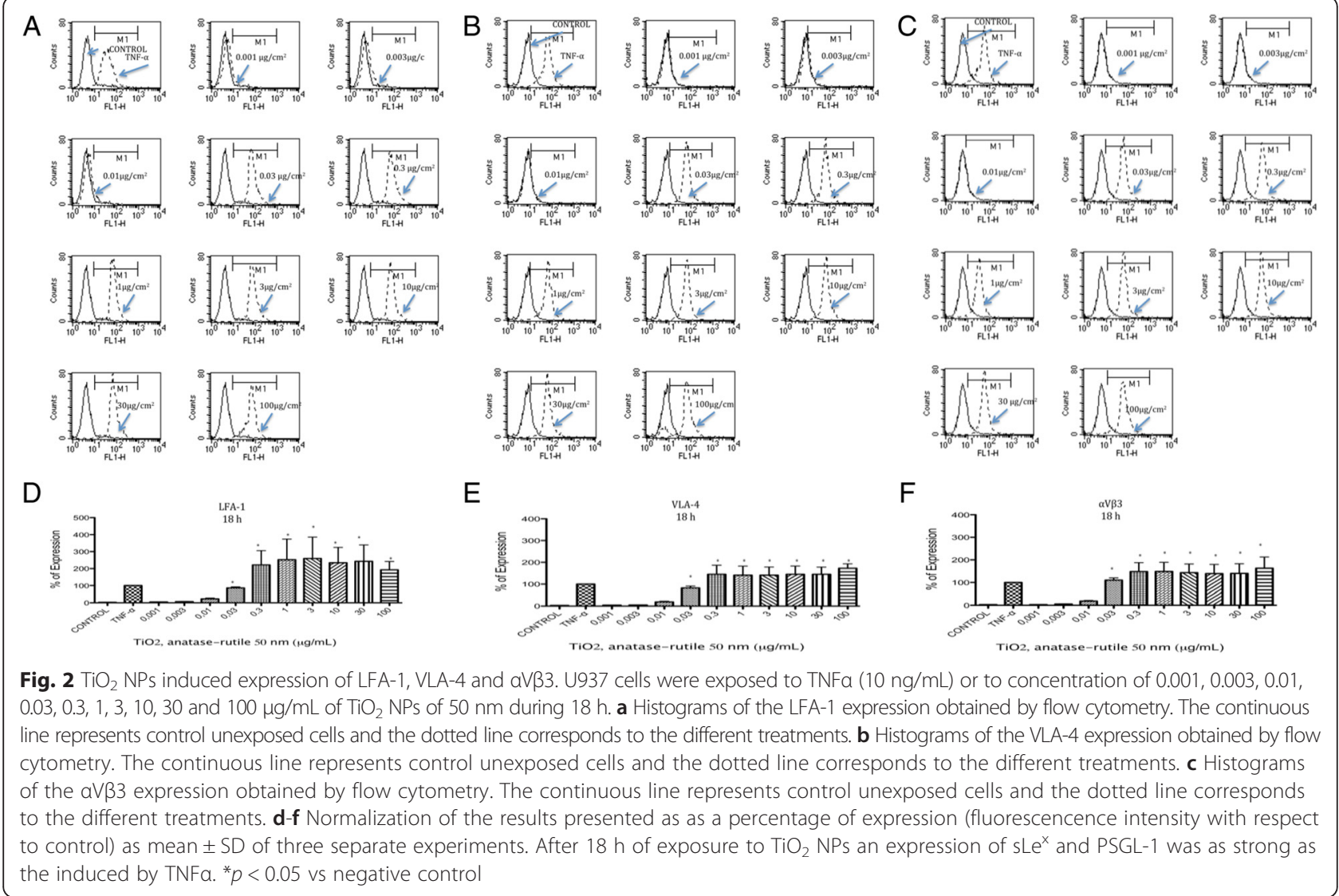

controls were observed as early as $8 \mathrm{~h}$ and as late as $24 \mathrm{~h}$ after exposure (Additional file 1). Concentrations from 0.001 to $0.01 \mu \mathrm{g} / \mathrm{mL}$ did not induce the expression of LFA-1, VLA-4 or $\alpha \mathrm{V} \beta 3$, but concentrations at $0.03 \mu \mathrm{g} / \mathrm{mL}$ and above did induce the expression of these molecules ( $p<0.05$ vs negative control) (Fig. 2).

\section{Adhesion assay}

When U937 cells were exposed to $\mathrm{TiO}_{2}$ NPs, the cells became adherent to naive HUVECs at all evaluated concentrations. The numbers of adherent cells induced were not different than the numbers induced by the positive controls ( $p<0.05$ vs negative control) (Fig. 3). Similar results were observed when the U937 cells and HUVECs were exposed to the same concentrations of $\mathrm{TiO}_{2} \mathrm{NPs}$ $(p<0.05$ vs negative control) (Fig. 3). If the HUVECs were exposed and the U937 cells were not exposed, there was no difference in the amount of adhesion induced ( $p<0.05$ vs negative control) (Fig. 3).

\section{Reactive oxygen species}

ROS were induced at all the tested concentrations at all tested times (10 min to $24 \mathrm{~h}$ ). At 10 and $30 \mathrm{~min}$ after exposure, the first changes in redox status occurred (Fig. 4a and b). After $2 \mathrm{~h}$, the redox statuses of the cells treated with lower concentrations of $\mathrm{TiO}_{2} \mathrm{NPs}$ fell under the levels of the positive controls, and only concentrations of $10 \mu \mathrm{g} / \mathrm{mL}$ or higher induced shifts in redox status as large as those of the positive controls $(p<0.05$ vs negative control) (Fig. 4c). After $4 \mathrm{~h}$ of exposure, all concentrations produced an effect above that of the positive controls in a concentration-dependent manner $(p<0.05$ vs negative control) (Fig. $4 \mathrm{~d}$ ). After $8 \mathrm{~h}$ and $24 \mathrm{~h}$, the shifts in redox statuses were equally large for all concentrations and were not different from that of the positive control ( $p<0.05$ vs negative control) (Fig. 4e-f).

$\mathrm{N}$-Acetil-Cystein (NAC decreased the expression of early adhesion molecules induced by $\mathrm{TiO}_{2} \mathrm{NPs}$. After exposure to $\mathrm{TiO} 2 \mathrm{NPs}$ during $3 \mathrm{~h}$ in the presence of NAC $(10 \mu \mathrm{m})$ the expression of sLex and PSGL-1 were abolished from 0.03 to $10 \mu \mathrm{g} / \mathrm{mL}$ (Fig. 5). When exposed to 30 and $100 \mu \mathrm{g} / \mathrm{mL}$ of $\mathrm{TiO} 2 \mathrm{NPs}$, the reduction of ROS by NAC was partial (Fig. 5).

Oxidative stress was determined indirectly by measuring the production of $\mathrm{H}_{2} \mathrm{O}_{2}$ by means of H2DCFDA. After $10 \mathrm{~min}$ and $4 \mathrm{~h}$ of exposure to $\mathrm{TiO}_{2} \mathrm{NPs}$, a large amount of accumulated $\mathrm{H}_{2} \mathrm{O}_{2}$ was detected, however, it was inhibited when the cells were previously treated with NAC (Fig. 6). At concentrations of 30 and $100 \mu \mathrm{g} / \mathrm{mL}$ of $\mathrm{TiO}_{2}$ NPs, the inhibition of ROS by NAC was partial (Fig. 6). 


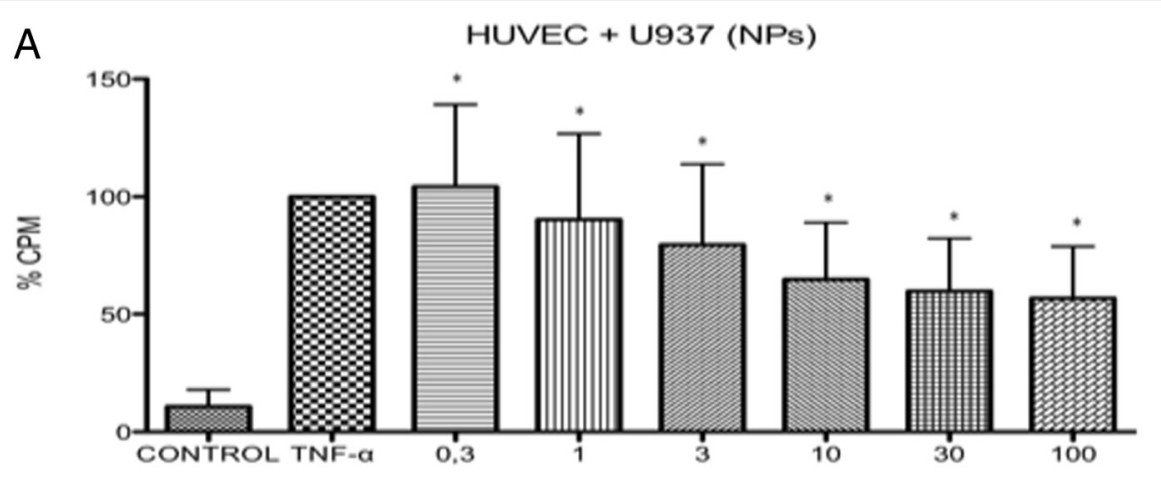

$\mathrm{TiO} 2$, anatase-rutile $50 \mathrm{~nm}(\mu \mathrm{g} / \mathrm{mL})$

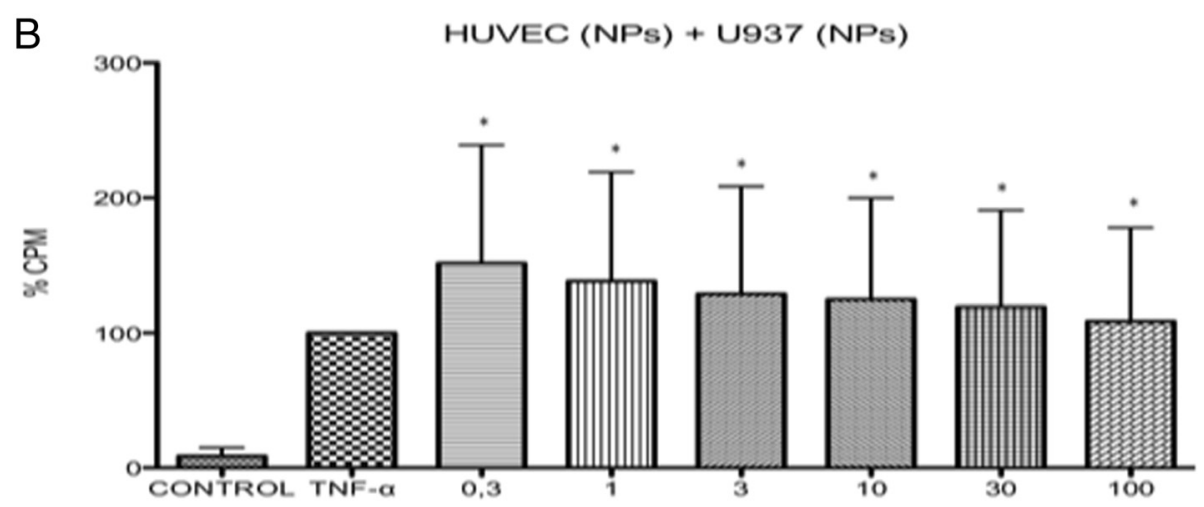

TiO2, anatase-rutile $50 \mathrm{~nm}(\mu \mathrm{g} / \mathrm{mL})$

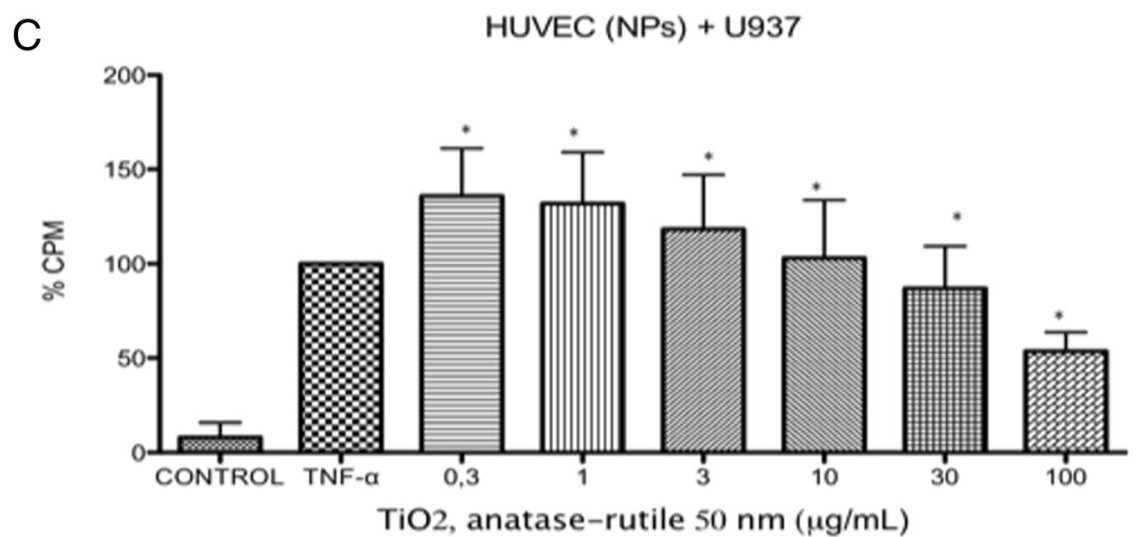

Fig. 3 Adhesion of U937 cells to HUVECs. U937 cells were exposed to TNFa (10 ng/mL) or to concentration of 0.3, 1, 3, 10, 30 and $100 \mu \mathrm{g} / \mathrm{mL}$ of TiO 2 NPs of $50 \mathrm{~nm}$ during $3 \mathrm{~h}$. Unexposed cultures were used as negative controls. After $3 \mathrm{~h}$ of exposure, the cells were co-cultured with HUVEC that may be naive or exposed to $\mathrm{TiO}_{2} \mathrm{NPS}$. a U937 cells exposed to $\mathrm{TiO}_{2} \mathrm{NPs}$ and naive HUVECs; $\mathbf{b}$ HUVEC and U937 cells exposed to the same concentrations of $\mathrm{TiO}_{2}-\mathrm{NP}$; $\mathbf{c} \mathrm{HUVEC}$ exposed to $\mathrm{TiO}_{2}-\mathrm{NP}$ and naive U937 cells. The results were similar under all experimental conditions. ${ }^{*} p<0.05$ vs negative control

\section{Discussion}

Translocation and systemic effects induced by inhaled particles has been documented in recent years [10, 16], supporting epidemiological evidence that visits to emergency rooms after high levels of particulate matter air pollution increase due to cardiovascular complications after high levels of particulate matter pollution [16, 28, 29]. Regarding the vascular effects of inhaled particles, some authors have reported decreases in coagulation time [30], increases in the numbers of circulating clots [31] and evidence of endothelial dysfunction in distant vessels [32]. Our results show that monocytes exposed to very small 


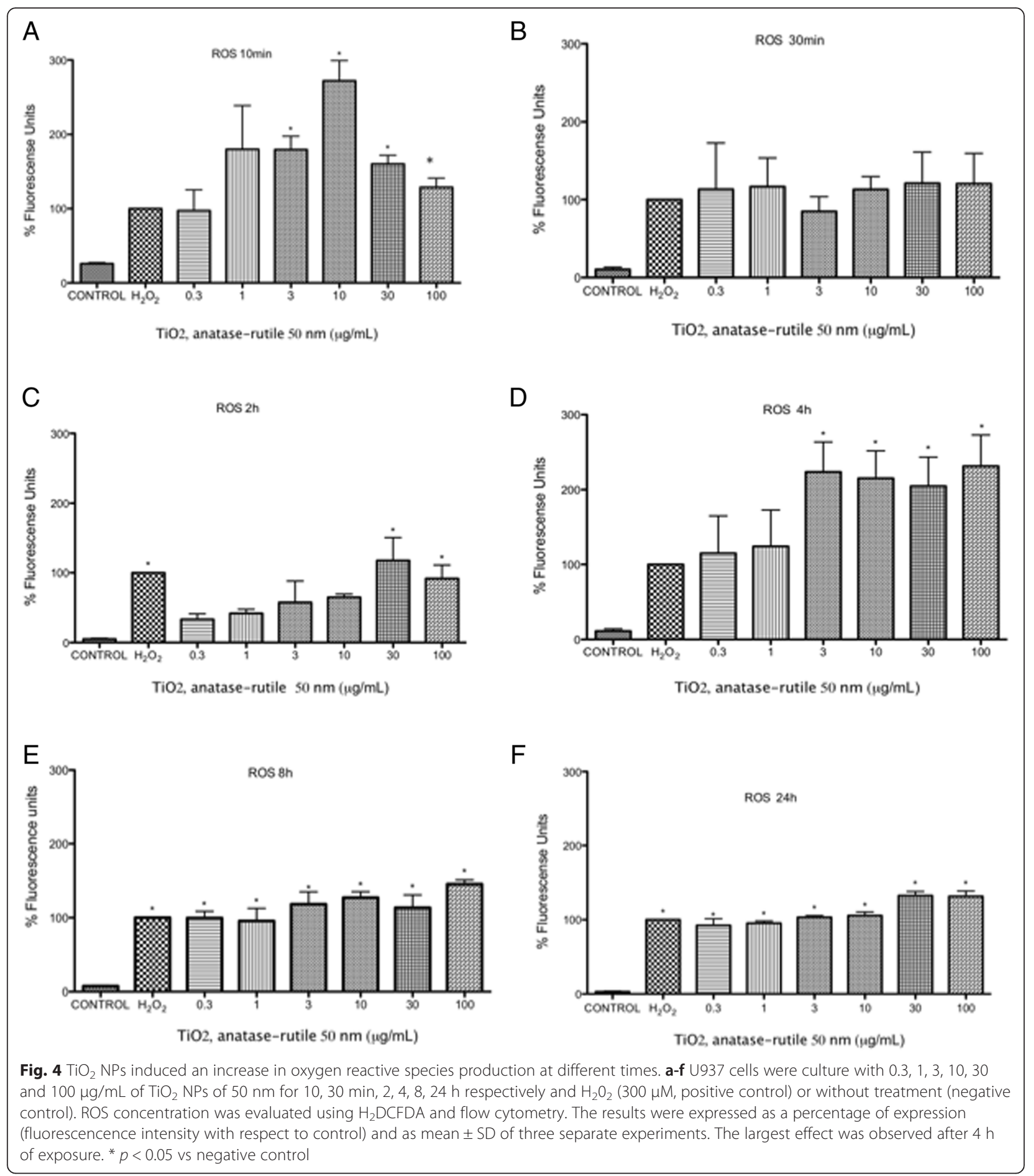

concentrations of $\mathrm{TiO}_{2}$ NPs express molecules that are ligands for adhesion molecules and that these monocytes become adherent to naive endothelial cells. Some controversial results on the effects of NPs have been shown when $\mathrm{ZnO}$ was compared to $\mathrm{TiO}_{2}$, reporting that THP-1 cells exposed to $\mathrm{ZnO}$ increases the expression of MCP-1, migration and adhesion to HUVECs, but $\mathrm{TiO} 2$ was unable to induce similar effects [33].

Moreover, we found that HUVECs exposed to nanoparticles became adherent to U937 cells regardless of whether they were naive or NP-stimulated. These effects were observed at higher concentrations of NP. We may 


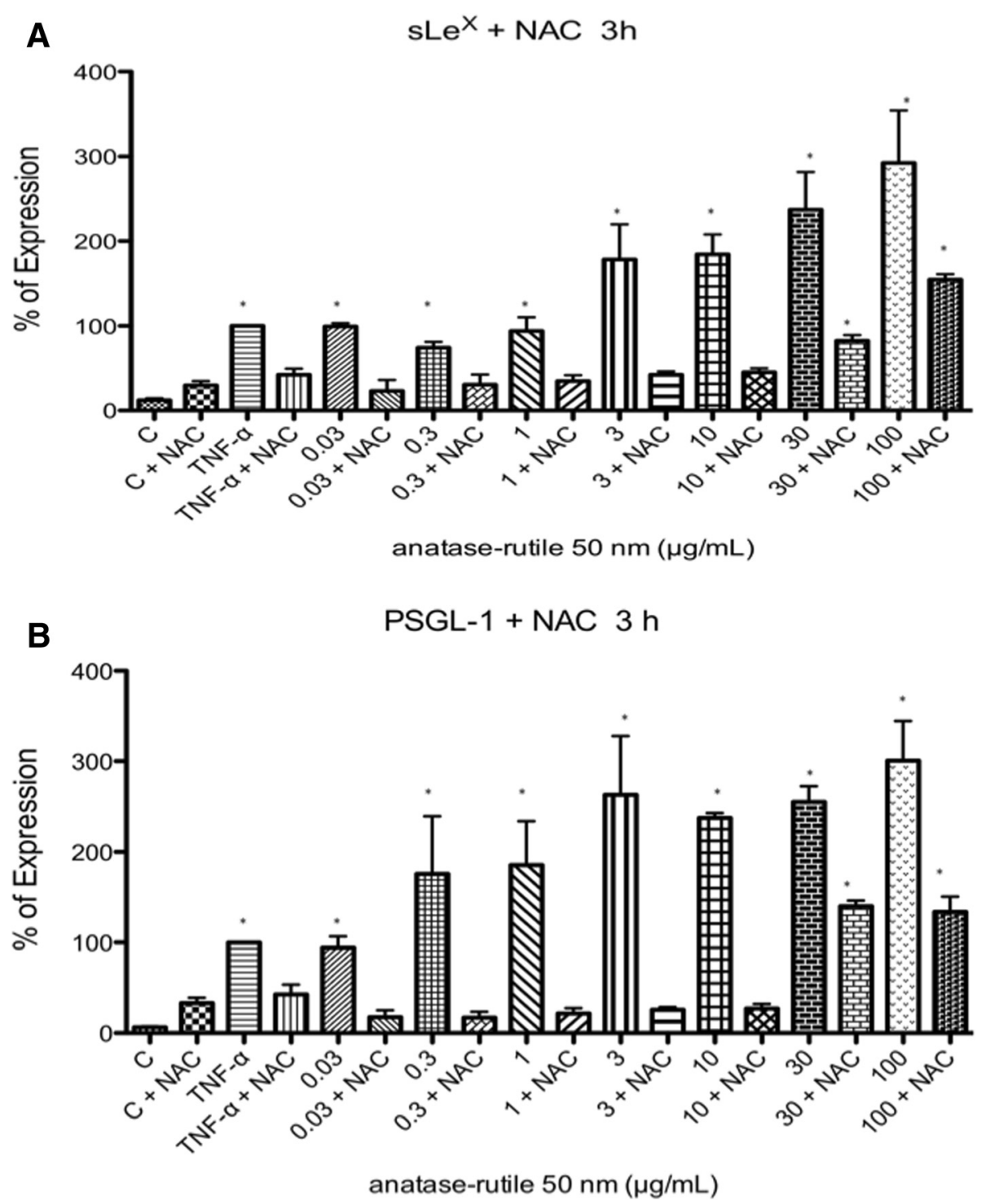

Fig. 5 The role of ROS in the expression of early receptors for adhesion molecules was assessed using NAC. After 1 h of incubation of U937 cells with or without $10 \mu \mathrm{M}$ of NAC, the cells were exposed to $0.03,0.3,0.1,0.3,1.0,3.0,10,30$ or $100 \mu \mathrm{g} / \mathrm{mL}$ of TiO $\mathrm{N}_{2} \mathrm{NPs}$. The presence of NAC abolished the expression of sLe $(\mathbf{a})$ and PSGL-1 (b) at concentration from 0.03 to $10 \mu \mathrm{g} / \mathrm{mL}$. When the cells were exposed to $30 \mathrm{or} 100 \mu \mathrm{g} / \mathrm{mL}$, the reduction of SLe $^{x}$ and PSGL-1 was partial in the presence of NAC

suppose that HUVECs treated with high concentrations of NP $(50-100 \mu \mathrm{g} / \mathrm{ml})$ lose their integrity due to shrinkage and cytoskeleton reorganization and become less adhesive [34]. $\mathrm{TiO}_{2} \mathrm{NPs}$ is widely used [11], and despite the fact that there are not enough data on exposure levels, our results indicate that even if small quantities of these particles come into contact with monocytes, systemic effects may be induced.

Humans have always been exposed to particles by inhalation due to natural events or anthropogenic activities [35]. Despite the many efforts to reduce the amounts of particles in work places [36] and cities [37] within the last 50 years, the increased production of new nanosized materials and already known materials leaves open questions regarding the toxicity and controllability of these materials. The case of $\mathrm{TiO}_{2}$ is interesting due to its wide use in different industries [11]. The fine particles of $\mathrm{TiO}_{2}$ were considered as poorly soluble and with low toxicity. In some studies has been shown that reducing $\mathrm{TiO}_{2}$ to nanosize, is related to an increase of the surface area as well as changes in their electronic configuration and reactivity. Nowadays the fine particles are considered by the IARC as a $2 \mathrm{~B}$ carcinogen, indicating that it is possibly carcinogenic for humans [12]. Other 


\section{$10 \mathrm{~min}$}

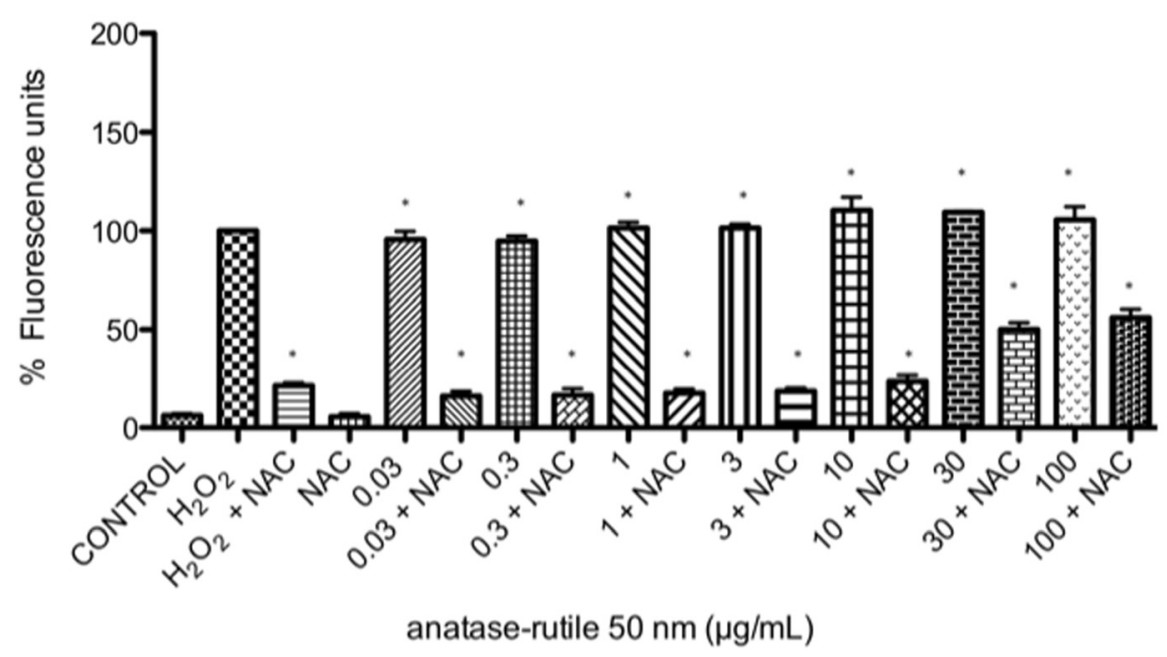

$4 \mathrm{~h}$

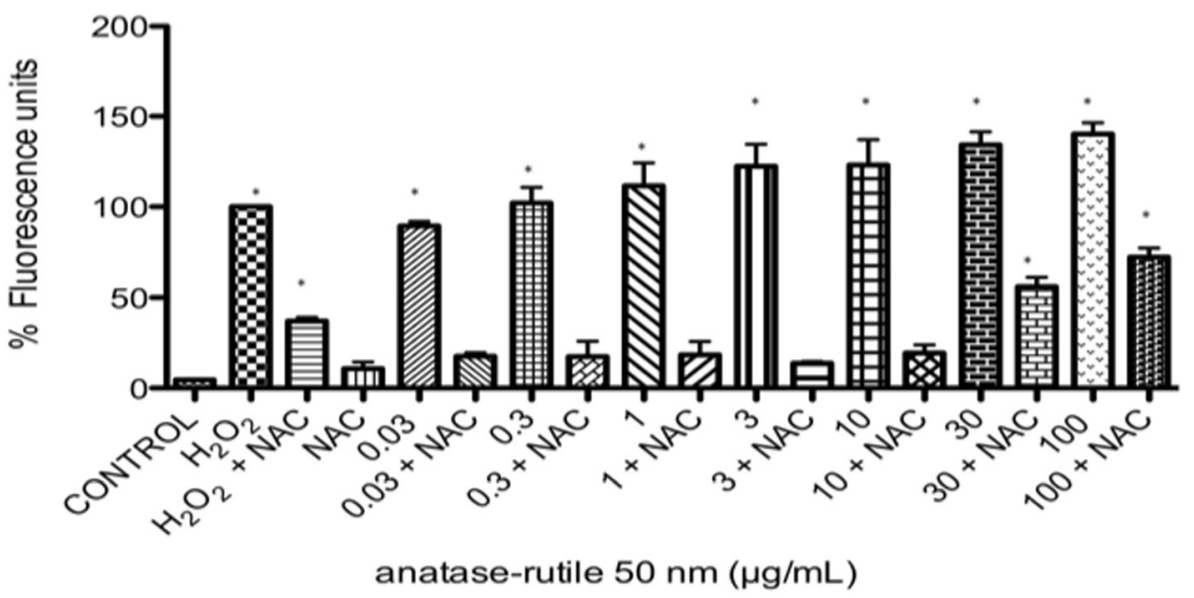

Fig. 6 Evaluation of the ROS levels in U937 cells exposed to $\mathrm{TiO}_{2} \mathrm{NPs}$ in the presence or absence of NAC. The presence of NAC in cultures of U937 cells exposed to $\mathrm{TiO}_{2} \mathrm{NPs}$ abolished the levels of $\mathrm{ROS}$, and only a partial reduction was observed if the cells were exposed to 30 or $100 \mathrm{\mu g} / \mathrm{mL}_{\mathrm{L}}$ of $\mathrm{Ti} \mathrm{O}_{2} \mathrm{NPs}$

studies suggest that differences in the sizes, charges and crystalline structures of the particles may be critical in their toxicity [38]. In the present study we evaluated three different types and sizes of $\mathrm{TiO}_{2} \mathrm{NPs}$ with different proportions of anatase and rutile (two main forms of $\mathrm{TiO}_{2}$ ). Because no difference was observed among the three types of $\mathrm{TiO}_{2}$ NPs evaluated, we focused only on the anatase-rutile with a size of $<50-\mathrm{nm}$, which was previously well characterized by us [17]. The results of the other two particles are presented as Additional file 1.

Vascular endothelium is the most important regulator of vascular homeostasis, both in physiological and pathophysiological conditions. Every alterations in endothelial functions are defined as 'endothelial dysfunctions', and these 'dysfunctional' processes have essential implications in the overall control of a vascular balance. Dysfunctional endothelium exhibit pro-thrombotic and proinflammatory activity which results in systemic response and vascular complications even in the peripheral regions of a vascular system [22-24]. It was clearly demonstrated that the prolonged and high dose pulmonary exposure of $\mathrm{TiO}_{2} \mathrm{NPs}$ promotes the progression and vulnerability of atherosclerotic plaques in ApoE-knockout mice [19, 20]. The possible mechanisms involve the increased expression or secretion of pro-thrombotic (tissue factor, plasminogen activator inhibitor-1) and pro-inflammatory factors (ICAM-1, VCAM-1, monocyte chemoattractant protein-1, factors) and reduction in levels of benign regulators (serum highdensity lipoprotein cholesterol - HDL, nitric oxide and tissue plasminogen activator - TPA) [20]. This deleterious 
effect of $\mathrm{TiO}_{2}$ is less significant or even moderate, if the dose and the time of exposure are reduced. Mikkelsen et al. demonstrated that repeated exposures to $\mathrm{TiO}_{2} \mathrm{NPs}$ was associated with modest plaque progression in the same animal model [21]. However, ex vivo endotheliumdependent acetylcholine ( $\mathrm{ACh}$ )-induced vasodilation of aorta segments from ApoE-knockout mice exposed by intratracheal instillation of $\mathrm{TiO}_{2}$ was significantly impaired in the presence of tempol (a free radical scavenger). This data suggest that locally generated free radicals contribute in endothelial dysfunction in its very primary phase [21].

Monocyte-endothelium interactions are mediated by different molecules promoting the capture, rolling, activation, adhesion, diapedesis and migration of monocytes [23]. Among these molecules, E, P and L selectins play an important role in capture and rolling events, whereas ICAM-1 and VCAM-1 play a main role in adhesion, and PECAM-1, in diapedesis [23]. Previously, we showed that endothelial cells exposed to urban $\mathrm{PM}_{10}$ and $\mathrm{PM}_{2.5}$ or $\mathrm{TiO}_{2} \mathrm{NPs}$ express these molecules at concentrations of 5 to $40 \mu \mathrm{g} / \mathrm{cm}^{2}[17,39,40,41]$. When the exposed cells were co-cultured with naive human monocytes, the monocytes adhered to the endothelial cells. It has been shown that animals exposed to particles have large amounts of monocytes that adhere to the endothelium in vessels distant from the lungs [32]. Given that only very small amounts of inhaled particles may translocate to the blood and that particle concentrations may drop due to diffusion, it is unlikely that inhaled particles activate endothelial cells in distant vessels. Nevertheless, circulating monocytes may capture small amounts of particles, and if the expression of the ligands for adhesion molecules is upregulated, then adhesion to distant vessels seems plausible. In the present study, we demonstrated that human monocytes exposed to concentrations of $\mathrm{TiO}_{2} \mathrm{NPs}$ as low as $0.03 \mu \mathrm{g} / \mathrm{mL}(30 \mathrm{ng} / \mathrm{mL}$ ) increases the expression of sLe ${ }^{\mathrm{x}}$ and PSGL-1 as early as $3 \mathrm{~h}$ (Fig. 1a-d), after exposure and LFA-1, VLA-4 and $\alpha \mathrm{V} \beta 3$ as early as $8 \mathrm{~h}$ after exposure (Additional file 1 ), reaching a peak $18 \mathrm{~h}$ after exposure (Fig. $2 \mathrm{a}-\mathrm{f}$ ). We evaluated the adhesion of exposed monocytes to endothelial cells. If monocytes were co-cultured with naive endothelial cells, the adhesion was as strong as when the endothelial cells exposed to particles were co-cultured with naive endothelial cells (Fig. 3). Previous observations of monocytes adhering to distant blood vessels could be explained by the activation of monocytes coming into contact with very small amounts of translocating particles. Another proposed mechanism of nanoparticle transfer involves their redistribution within microvesicles released from activated macrophages. Intercellular trafficking of magnetic labeled nanoparticles has been observed between NP-stimulated macrophages and naïve monocytes [22]. Moreover it has been observed that the nanoparticles can be internalized within the cell; NPs first interact with the cell membrane and are subsequently internalized by vesicles, or by diffusion. Nevertheless in other repots it has been observed that nanoparticles are internalize into the cell, by other mechanisms such as phagocytosis and endocytosis.

When monocytes and endothelial cells were independently exposed to $\mathrm{TiO}_{2} \mathrm{NPs}$ for $3 \mathrm{~h}$ and then co-cultured for another $3 \mathrm{~h}$, the intensity of cellular adhesion was similar to that of previous experiments. The ability of $\mathrm{TiO}_{2}$ NPs stimulated endothelial cells to attach to monocytes may be evoked not only by the expression of adhesion receptors but also by changes in the physical properties of their cell surfaces, e.g., as seen after phosphatidylserine (PS) exposure. PS is normally restricted to the inner leaflet of the plasma membrane but in stressful conditions becomes exposed on the outer surface of viable endothelial cells and participates in macrovesicles shedding [42]. PS may activate monocytes and facilitate their adhesion to endothelial cells by an annexin-1dependent mechanism [43]. In our study we did not investigate this interaction but cannot exclude the involvement of this specific mechanism.

Oxidative stress seems to play a central role in the effect of $\mathrm{TiO}_{2} \mathrm{NPs}$ on monocytes. An initial large disruption of redox balance was observed after $10 \mathrm{~min}$ of exposure, which dropped after $30 \mathrm{~min}$ of exposure (Fig. 4). A more consistent concentration-response effect was observed after 2 and $4 \mathrm{~h}$. After 8 and $24 \mathrm{~h}$ of exposure, the levels of redox balance were not different at the evaluated concentrations but were all as high as in the positive controls. Previous studies have shown the role of redox balance in the expression of the molecules we evaluated and therefore support our observations [44]. These results are interesting due to the role of the PSGL-1 involved in the development of several outcomes such thrombosis and cardiovascular diseases. In addition the PSGL-1 regulate the expression of other molecules involved in the inflammatory response. The interaction between the P-selectin and PSGL- 1 activates the beta- 2 integrin Mac-1 and the firm adhesion between the two cell types. The interaction of P-selectin with PSGL-1 also induces upregulation of leukocyte tissue factor, biosynthesis of several cytokines and other inflammatory reactions, thereby contributing to the thrombotic progression, therefore we suggest that the increase of PSGL-1 in the monocytes exposure could be implicated in development cardiovascular effects, however it is necessary to do more researcher of the role of PSGL1 in the activation monocytes during the inflammatory process $[45,46]$.

\section{Conclusions}

In conclusion, $\mathrm{TiO}_{2}$ NPs are capable of activating human monocytes at very low concentrations by increasing the 
expression of adhesion molecules ligands, which triggers monocyte-endothelial cell adhesion. These effects are dependent of the production of ROS.

\section{Methods}

\section{Experimental design}

Human cell line U937 was used as a monocyte cell model and HUVECs were used as a model for endothelial cells in the adhesion assays. Cells were exposed to $0.001,0.003,0.01,0.03,0.3,1,3,10,30$ or $100 \mu \mathrm{g} / \mathrm{mL}$ of each type of $\mathrm{TiO}_{2} \mathrm{NPs}$. Unexposed cells were used as negative controls, and cells exposed to TNF $\alpha$ were used as positive controls. To evaluate the expression of $\mathrm{SLe}^{\mathrm{x}}$, PSGL-1, LFA-1, VLA- 4 and $\alpha \mathrm{V} \beta 3$, cells were exposed to $\mathrm{TiO}_{2}$ NPs for 3 to $24 \mathrm{~h}$. The expression of different molecules was measured by flow cytometry using monoclonal antibodies labeled with FIT-C. All experiments were repeated at least three times. The role of ROS was evaluated by using NAC.

The adhesion of monocytes to endothelial cells was evaluated under three different conditions as follows (Fig. 7): Monocytes labeled with $\left[{ }^{3} \mathrm{H}\right]$-thymidine were exposed to $0.3,1,3.0,10,30$ and $100 \mu \mathrm{g} / \mathrm{mL}$ of $\mathrm{TiO}_{2} \mathrm{NPs}$ for $3 \mathrm{~h}$ and then added to naive endothelial cells. In the second approach, $\left[{ }^{3} \mathrm{H}\right]$-thymidine labeled monocytes were exposed to the same concentrations of $\mathrm{TiO}_{2} \mathrm{NPs}$ for $3 \mathrm{~h}$ and then added to previously HUVECs previously exposed to the same concentrations of $\mathrm{TiO}_{2} \mathrm{NPs}$. The third approach involved exposing HUVECs to $\mathrm{TiO}_{2}$ NPs concentrations and adding naive thymidine labeled monocytes after $3 \mathrm{~h}$. After co-culturing both cell types during $3 \mathrm{~h}$, the cultures were washed and then lysed. Unexposed cultures were used as negative controls, and cells exposed to TNFo $(10 \mathrm{ng} / \mathrm{mL})$ were used as positive controls.

\section{Materials}

RPMI 1640 and M199 media and trypsin were purchased from GIBCO/BRL (Grand Island, NY, USA), and fetal bovine serum (FBS) was purchased from HyClone (Logan, UT, USA). Sterile plastic material for tissue culture was purchased from NUNC and Corning. Flow cytometry reagents were purchased from Becton Dickinson, Immunocytometry Systems (San José, CA, USA). TNF $\alpha$ was purchased from R \& D Systems (Minneapolis, MN, USA). A peroxidase-labeled monoclonal antibody against Von Willebrand factor was purchased from Santa Cruz Biotechnology (Santa Cruz, CA, USA). H2DCFDA was purchased from Molecular Probes.

Titanium dioxide nanoparticles We used three different types of $\mathrm{TiO}_{2}$ NPs as follows: $<25 \mathrm{~nm}$ anatase (Sigma-Aldrich 637254) with a surface of $45-50 \mathrm{~m}^{2} / \mathrm{g}$,

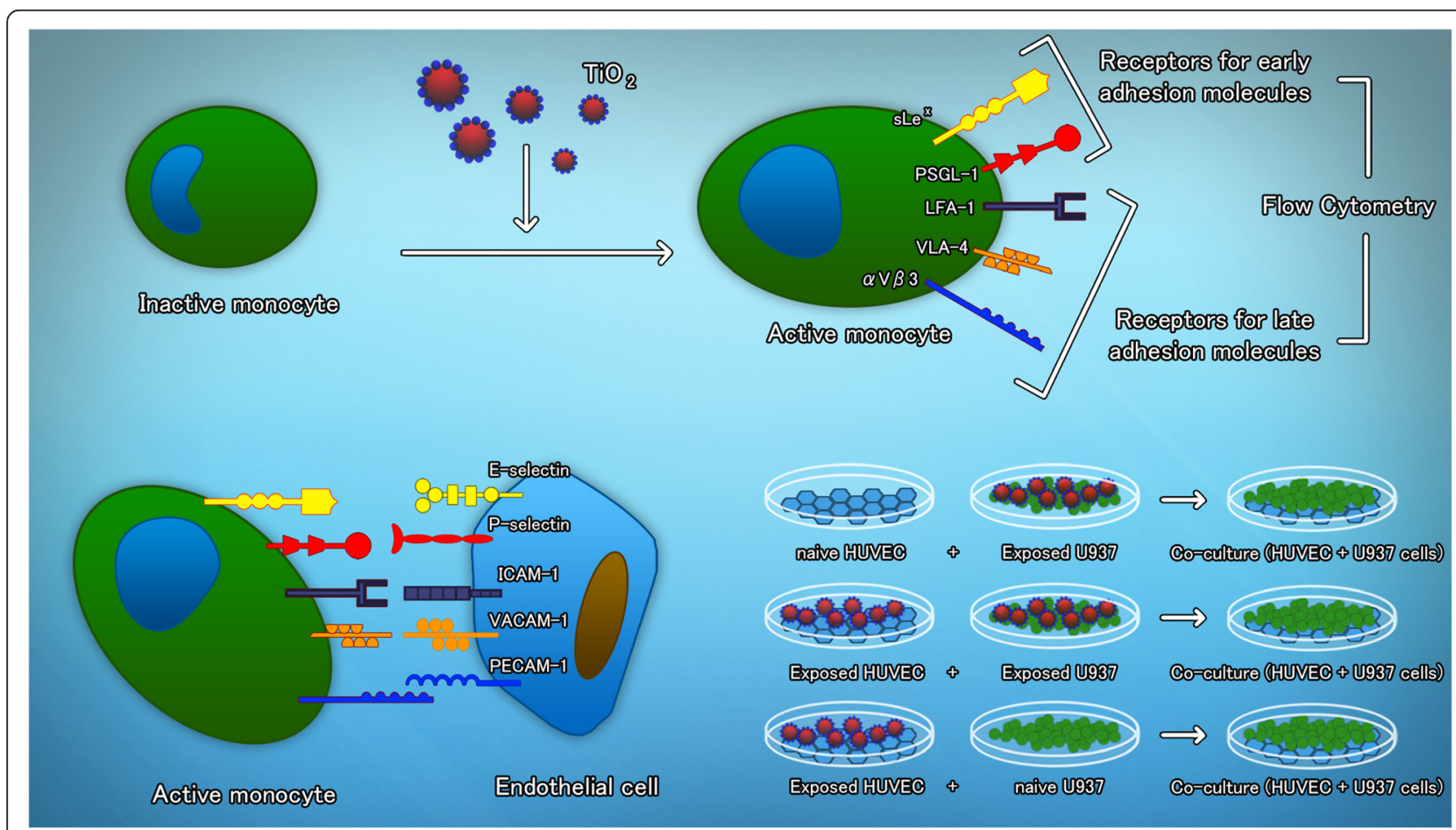

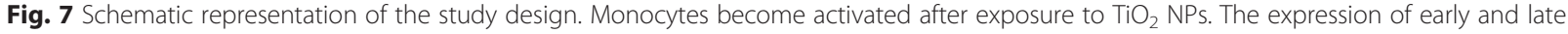
receptors for adhesion molecules was evaluated by means of flow cytometry. Different combinations of exposure to $\mathrm{TiO}_{2} \mathrm{NPs}_{\mathrm{s}}$ were used to evaluate if the monocytes become adherent to endothelial cells 
$50 \mathrm{~nm}$ anatase-rutile [8] with a surface of $46 \mathrm{~m}^{2} / \mathrm{g}$ and $100 \mathrm{~nm}$ anatase-rutile (Sigma-Aldrich 634662). All particles were tested for the presence of endotoxin by a kinetic chromogenic Limulus Amebocyte Lysate (LAL). We used X-ray Fluorescence (XRF) analysis to determine if other elements (Al, Si, P, S, Cl, K, Ca, Ti, V, Cr, Mn, Fe, $\mathrm{Ni}, \mathrm{Cu}, \mathrm{Zn}, \mathrm{Se}, \mathrm{Br}, \mathrm{Sr}$, and $\mathrm{Pb}$ ) were present in the particles. The $50 \mathrm{~nm}$ anatase-rutile used in this study was previously characterized by our work group [17].

The $<25 \mathrm{~nm}$ anatase and the $<100 \mathrm{~nm}$ anatase-rutile were evaluated by means of zetasizer (Zetasizer Nano ZSP, Malvern Instruments LTD, Worcestershire UK) and the mean particle size and $\zeta$-potential was measured.

$\mathrm{TiO}_{2}$ NPs were handled under light-free conditions at all times. $\mathrm{TiO}_{2} \mathrm{NPs}$ were sterilized by autoclave $(1.5 \mathrm{~atm}$, $20 \mathrm{~min}$ ) the night before each experiment. Suspensions of $\mathrm{TiO}_{2} \mathrm{NPs}$ in M199 medium $(1 \mathrm{mg} / \mathrm{mL})$, were prepared a few minutes before cell exposure. Aliquots were taken from these suspensions and further diluted with culture medium until the required final concentration was obtained. During the incubation periods, the exposed cells remained in the light-free conditions.

Culture of U937 Cells Human leukemia promonocytic U937 cells were cultured in RPMI-1640 medium supplemented with $10 \%$ FBS and L-glutamine $(2 \mathrm{mM})$. We exposed 400,000 cells to $0.001,0.003,0.01,0.03,0.3,1,3$, 10,30 and $100 \mu \mathrm{g} / \mathrm{mL}$ of each type of $\mathrm{TiO}_{2} \mathrm{NPs}$ or human recombinant TNF $\alpha(10 \mathrm{ng} / \mathrm{mL})$.

Endothelial cell cultures Primary human umbilical endothelial vein cell (HUVEC) cultures were obtained by proteolytic dissociation of umbilical cord veins from normal deliveries, treated with collagenase type II $(0.2 \mathrm{mg} /$ $\mathrm{mL}$ ), and cultured on $0.02 \%$ gelatin-coated culture dishes in M199 supplemented with 10 \% FBS, glutamine $(2 \mathrm{mM})$, heparin $(1 \mathrm{mg} / \mathrm{mL})$, and endothelial mitogen $(20 \mu \mathrm{g} / \mathrm{mL})$ as previously described [47]. Cells on their second passage were used for all experiments. The phenotype of the HUVEC cultures was confirmed by Von Willebrand antigen staining.

Evaluation of adhesion molecule receptor expression by flow cytometry To evaluate the expression of $\mathrm{sLe}^{\mathrm{x}}$ and PSGL-1, cells were exposed during 3, 6, 9, 12 or $24 \mathrm{~h}$. To evaluate the expression of LFA- 1 , VLA- 4 and $\alpha V \beta 3$ cells were exposed for $3,8,12,18$ or $24 \mathrm{~h}$. After these times, the cells were collected and centrifuged at $1200 \mathrm{rpm}$ for $3 \mathrm{~min}$. The cells were incubated with the different FITC-labeled monoclonal antibodies against human adhesion molecules receptor diluted 1:20. After $1 \mathrm{~h}$ of incubation, the cells were washed twice with PBSalbumin (8\% albumin and $0.02 \%$ sodium azide), resuspended in $500 \mu \mathrm{L}$ PBS, and immediately analyzed by flow cytometry (Fascalibur, Becton Dickinson). The results are expressed as percentages of expression compared with positive control cultures. To calculate the intensity of expression, we used the number of cells positive for FITC (FL1-H) multiplied by the mean of the fluorescence units (FU). The results for FU for the control cultures were considered $100 \%$ and all the other data points were related to the positive controls to calculate the relative percentages of expression.

Adhesion of U937 cells to endothelial cells Adhesion was evaluated using U937 cells labeled with $\left[{ }^{3} \mathrm{H}\right]$-thymidine and exposed to $0.001,0.003,0.01,0.03,0.3,1,3,10$, 30 and $100 \mu \mathrm{g} / \mathrm{mL}$ of each type of $\mathrm{TiO}_{2}$ NPs for $3 \mathrm{~h} ; 1 \times$ $10^{5}$ HUVECs were seeded in 24-well tissue culture plates with $1 \mathrm{~mL}$ of supplemented M199 medium. Naive cultures were used to evaluate the adhesion of exposed monocytes. In other experiments, HUVEC were treated with TNF- $\alpha(10 \mathrm{ng} / \mathrm{mL})$ or $\mathrm{TiO}_{2}$-NP, whereas $6 \times 10^{6}$ U937 cells were incubated with $30 \mu \mathrm{Ci}$ of $\left[{ }^{3} \mathrm{H}\right]$-thymidine for $48 \mathrm{~h}$. HUVECs (naive or pretreated) were cocultured with $5 \times 10^{5}$ U937 cells/well (pretreated with $\mathrm{TiO}_{2}-\mathrm{NP}$ or naive) for $3 \mathrm{~h}$. At the endpoint, each well was washed to eliminate any U937 cells not attached to the HUVECs, and the cells were fixed with $95 \%$ methanol and lysed with $\mathrm{NaOH}(200 \mathrm{mM})$ for 12 h. Radioactivity was determined with a scintillation counter (Beckman Coulter model LS6500, Miami, FL, USA), and counts per minute (CPM) were considered directly proportional to the number of U937 cells adherent to the HUVECs.

Measurement of Reactive Oxygen Species (ROS) in U937 cells The oxidation of 2, 7-dichlorodihydrofluore scein diacetate $\left(\mathrm{H}_{2} \mathrm{DCFDA}\right)$ into 2, 7-dichlorodihydro fluorescein (DCF) was used to assess ROS generation. U937 were cultured without or with three different types $\mathrm{TiO}_{2}-\mathrm{NP}(0.001,0.003,0.01,0.03,0.3,1,3,10,30$ or $100 \mu \mathrm{g} / \mathrm{mL}$ ) for $10,30 \mathrm{~min}, 2,4,8$ and $24 \mathrm{~h} . \mathrm{H}_{2} \mathrm{O}_{2}$ $(500 \mu \mathrm{M})$ was used as a positive control to induce ROS. After treatment, cells were incubated with $\mathrm{H}_{2}$ DCFDA $(10 \mu \mathrm{M})$ for $30 \mathrm{~min}$ at $37^{\circ} \mathrm{C}$ and washed twice with PBS. After an extensive wash, fluorescence was evaluated by flow cytometry (Facscalibur, Becton Dickinson). The mean fluorescence intensity was calculated by multiplying the number of events (fluorescent cells) by the mean of the intensity presented by the Cell Quest software used for the analysis. Cultures exposed to $\mathrm{H}_{2} \mathrm{O}_{2}$ were considered as $100 \%$ and all the other data points were related to the positive control to calculate the relative induction of ROS.

N-Acetil-Cisteína (NAC) and ROS production U937 were cultured without or with $\mathrm{NAC}(10 \mu \mathrm{M})$ and $\mathrm{TiO}_{2}$ 
NPs $(0.001,0.003,0.01,0.03,0.3,1,3,10,30$ or $100 \mu \mathrm{g} /$ $\mathrm{mL}$ ) for $10 \mathrm{~min}$ and $4 \mathrm{~h}$, and $\mathrm{PM}_{10}$ or in combination for $3 \mathrm{~h}$. NAC was added $1 \mathrm{~h}$ before particles. $\mathrm{H}_{2} \mathrm{O}_{2}$ $(500 \mu \mathrm{M})$ was used as positive control to induce oxidative stress. After treatment, cells were incubated with $\mathrm{H}_{2}$ DCFDA $(10 \mu \mathrm{M})$ for $30 \mathrm{~min}$ at $37^{\circ} \mathrm{C}$ and washed twice with PBS. After extensive wash, fluorescence was evaluated by flow cytometry (Facscalibur, Becton Dickinson). The mean fluorescence intensity was calculated by multiplying the number of events (fluorescent cells) by the mean of the intensity presented by the Cell Quest software used for the analysis.

\section{Statistical analysis}

Multiple comparisons were carried out by one-way ANOVA, followed by Fisher's LSD multiple comparison test. Differences were considered statistically significant when $p<0.05$.

\section{Additional file}

Additional file 1: Results of the expression of early receptors for adhesion molecules at 6 and $9 \mathrm{~h}$ induced by $\mathrm{TiO}_{2} \mathrm{NPs}$ with a size of 50 $\mathrm{nm}$. Results of the expression of late receptors for adhesion molecules at 8 and $12 \mathrm{~h}$ induced by $\mathrm{TiO}_{2}$ NPs with a size of $50 \mathrm{~nm}$. Results of viability of U937 cells exposed to $\mathrm{TiO}_{2}$ during $3,6,9,12$ or $18 \mathrm{~h}(0.001$ to $100 \mu \mathrm{g} /$ $\mathrm{cm}^{2}$ ). Results of the expression of early and late receptors for adhesion molecules induced by $\mathrm{TiO}_{2}$ NPs with a size of $25 \mathrm{~nm}$ (time-course, 3 to $24 \mathrm{~h}$ ). Results of the expression of early and late receptors for adhesion molecules induced by $\mathrm{TiO}_{2}$ NPs with a size of $100 \mathrm{~nm}$ (time-course, 3 to $24 \mathrm{~h})$. (DOCX $4681 \mathrm{~kb})$

\section{Abbreviations}

CPM, counts per minute; FBS, fetal bovine serum; FU, fluorescence units; $\mathrm{H}_{2}$ DCFDA, 2, 7-dichlorodihydrofluorescein diacetate; HUVECs, human umbilical vein endothelial cells; IARC, International Agency for Research on Cancer; NAC, $\mathrm{N}$-acetylcysteine; $\mathrm{ROS}$, reactive oxygen spicies; $\mathrm{TiO}_{2} \mathrm{NPS}$, titanium dioxide nanoparticles

\section{Acknowledgments}

We would like to thank Leticia Martínez, Eva Salinas, Dr. Javier Miranda and Juan Carlos Pineda Santamaría for their technical support. CRR and GHP are students of the Universidad Interserrana del Estado de Puebla. RQB is a PhD student at the Ciencias de la tierra program in the Universidad Nacional Autónoma de México. EHG is a PhD student at the Escuela de Ciencias Biológicas of the Instuto Politécnico Nacional.

\section{Funding}

This study was funded by Consejo Nacional de Ciencia y Tecnología (CONACyT), Grant number 106057.

\section{Availability of data and material}

The data supporting our conclusions is included in the main body of the manuscript or in the Additional file 1.

\section{Authors' contributions}

All authors have read and approved the final manuscript. CRR did most of the experiments and participate in the preparation of the figures. GHP, PRG, IVL and EHG did participate in obtaining HUVECs and performing different experiments. RQB did the evaluation of endotoxin and elemental content of the particles. ES participate in the preparation of the manuscript. RLM provide the facilities for flow cytometry, provide advice on the performance of experiments and participate in the preparation of the final manuscript. AMD and EAM designed the study, coordinate the laboratory work and prepare the final manuscript and figures.

\section{Competing interests}

The authors declare that they have no competing interests.

\section{Consent for publication}

No personal information is included in this study.

Ethics approval and consent to participate

No humans or animals were used in this study.

\section{Author details}

${ }^{1}$ Environmental Toxicology Laboratory, Subdirección de Investigación Básica, Instituto Nacional de Cancerología, Ciudad de México, México. ${ }^{2}$ Universidad Interserrana del Estado de Puebla, Ahuacatlán, Puebla, México. ${ }^{3}$ Electron Microscopy Laboratory, Subdirección de Patología, Instituto Nacional de Cancerología, Ciudad de México, México. ${ }^{4}$ Cell Biology Laboratory, Physiology Department, Instituto Nacional de Cardiología, Ciudad de México, México. ${ }^{5} \mathrm{M}$. Smoluchowski Institute of Physics, Jagiellonian University, Krakow, Poland. 'Swedish Toxicology Sciences Research Center (Swetox), Forskargatan 20, 15136 Södertälje, Sweden.

Received: 17 October 2015 Accepted: 17 June 2016

Published online: 23 June 2016

\section{References}

1. Zhao J, Castranova V. Toxicology of nanomaterials used in nanomedicine. Toxicol Environ Health B Crit Rev. 2011;14:593-632.

2. Cho WS, Kang BC, Lee JK, Jeong J, Che JH, et al. Comparative absorption, distribution, and excretion of titanium dioxide and zinc oxide nanoparticles after repeated oral administration. Part Fibre Toxicol. 2013;10:9.

3. Long TC, Tajuba J, Sama P, Saleh N, Swartz C, et al. Nanosize titanium dioxide stimulates reactive oxygen species in brain microglia and damages neurons in vitro. Environ Health Perspect. 2007;115:1631-7.

4. Li SQ, Zhu RR, Zhu H, Xue M, Sun XY, et al. Nanotoxicity of $\mathrm{TiO}_{2}$ nanoparticles to erythrocyte in vitro. Food Chem Toxicol. 2008;46:3626-31.

5. Magaye R, Zhao J. Recent progress in studies of metallic nickel and nickelbased nanoparticles' genotoxicity and carcinogenicity. Environ Toxicol Pharmacol. 2012;34:644-50.

6. Zhao J, Bowman L, Zhang X, Vallyathan V, Young SH, et al. Titanium dioxide $\left(\mathrm{TiO}_{2}\right)$ nanoparticles induce JB6 cell apoptosis through activation of the caspase8/Bid and mitochondrial pathways. J Toxicol Environ Health A. 2009;72:1141-9.

7. Buzea C, Pacheco II, Robbie K. Nanomaterials and nanoparticles: sources and toxicity. Biointerphases. 2007;2:17-71.

8. Jawad H, Boccaccini AR, Ali NN, Harding SE. Assessment of cellular toxicity of $\mathrm{TiO}_{2}$ nanoparticles for cardiac tissue engineering applications. Nanotoxicology. 2011;5:372-80.

9. Oberdörster G, Elder A, Rinderknecht A. Nanoparticles and the brain: cause for concern? J Nanosci Nanotechnol. 2009;9(8):4996-5007.

10. Nemmar A, Holme JA, Rosas I, Schwarze P, Alfaro-Moreno E. Recent advances in particulate matter and nanoparticle toxicology: a review of the in vivo and in vitro studies. Biomed Res Int. 2013;2013:279371.

11. Shi H, Magaye R, Castranova V, Jinshun Z. Titanium dioxide nanoparticles: a review of current toxicological data. Part Fibre Toxicol. 2013;10:15.

12. International Agency for Research on Cancer. IARC Monographs on the Evaluation of Carcinogenic Risks to Humans, VOLUME 93: Carbon Black, Titanium Dioxide, and Talc. Lyon: International Agency for Research on Cancer; 2010.

13. Cohen JM, Derk R, Wang L, Godleski J, Kobzik L, Brian J, Phillip D. Trancking translocation of industrially relevant engineered nanomaterials (ENMs) across alveolar epithelial monolayers in vitro. Nanotoxicology. 2014;8:216-25.

14. Geys J, Cohenegrachts L, Vercammen J, Engelborghs Y, Nemmar A, Nemery $B$, et al. In vitro study of the pulmonary translocation of nanoparticles: A preliminary study. Toxicol Lett. 2006;160(3):218-26.

15. Petitot F, Lestaevel $P$, Tourlonias E, Mazzucco C, Jacquinot $S$, Dhieux B, et al. Inhalation of uranium nanoparticles: Respiratory tract deposition and translocation to secondary target organs in rats. Toxicol Lett. 2013;217:217-25.

16. Nemmar A, Hamoir J, Nemery B, Gustin P. Evaluation of particle translocation across the alveolo-capillary barrier in isolated perfused rabbit lung model. Toxicology. 2005;208(1):105-13.

17. Montiel-Davalos A, Ventura-Gallegos JL, Alfaro-Moreno E, Soria-Castro E, Garcia-Latorre E, Cabañas-Moreno JG, et al. TiO2 Nanoparticles Induce Dysfunction and Activation of Human Endothelial Cells. Chem Res Toxicol. 2012;25(4):920-30. 
18. Ramos-Godinez MP, Gonzalez-Gomez BE, Montiel-Davalos A, Lopez-Marure R Alfaro-Moreno E. TiO2 nanoparticles induce endothelial cell activation in a pneumocyte-endothelial co-culture model. Toxicol in Vitro. 2013;27(2):774-81.

19. Chen T, Hu J, Chen C, Pu J, Cui X, Jia G. Cardiovascular effects of pulmonary exposure to titanium dioxide nanoparticles in ApoE knockout mice. J Nanosci Nanotechnol. 2013;13:3214-22.

20. Yu X, Zhao X, Ze Y, Wang L, Liu D, Hong J, et al. Changes of serum parameters of $\mathrm{TiO}_{2}$ nanoparticle-induced atherosclerosis in mice. J Hazard Mater. 2014;280:364-71.

21. Mikkelsen L, Sheykhzade M, Jensen KA, Saber AT, Jacobsen NR, Vogel U, et al. Modest effect on plaque progression and vasodilatory function in atherosclerosis-prone mice exposed to nanosized TiO(2). Part Fibre Toxicol. 2011;8:32. doi:10.1186/1743-8977-8-32.

22. Luciani N, Wilhelm C, Gazeau F. The role of cell-released microvesicles in the intercellular transfer of magnetic nanoparticles in the monocyte/ macrophage system. Biomaterials. 2010;31(27):7061-9.

23. Muller WA. Leukocyte-endothelial cell interactions in the inflammatory response. Lab Invest. 2002;82(5):521-33.

24. Mulligan MS, Warner RL, Rittershaus CW, Thomas L. Endothelial targeting and enhanced antiinflammatory effects of complement inhibitors possessing sialyl Lewisx moieties. J Immunol. 1999;162(8):4952-9.

25. Traunecker E, Gardner R, Fonseca JE, Polido-Pereira J, Seitz M, Villiger PM, et al. Blocking of LFA-1 enhances expansion of Th17 cells induced by human CD14 + CD16++ nonclassical monocytes. Eur J Immunol. 2015;45(5):1414-25.

26. Chakraborty S, Hu SY, Wu SH, Karmenyan A, Chiou A. The Interaction Affinity between Vascular Cell Adhesion Molecule-1 (VCAM-1) and Very Late Antigen-4 (VLA-4) Analyzed by Quantitative FRET. PLoS One. 2015;10(3):e0121399.

27. Buckley C, Doyonnas R, Newton J, Blystone S, Brown E, Watt S, Simmons D. Identification of alpha $v$ beta 3 as a heterotypic ligand for CD31/PECAM-1. J Cell Sci. 1996;109:437-45.

28. Lu F, Xu D, Cheng Y, Dong S, Guo C, Jiang X, et al. Systematic review and meta-analysis of the adverse health effects of ambient PM2.5 and PM10 pollution in the Chinese population. Environ Res. 2015;136:196-204.

29. Atkinson R, Kang S, Anderson H, Mills I, Walton HA. Epidemiological time series studies of PM2.5 and daily mortality and hospital admissions: a systematic review and meta-analysis. Thorax. 2014;69:660-5.

30. Nemmar A, Subramaniyan D, Yasin J, Ali BH. Impact of experimental type 1 diabetes mellitus on systemic and coagulation vulnerability in mice acutely exposed to diesel exhaust particles. Part Fibre Toxicol. 2013;10:14.

31. Nemmar A, Hoet PH, Dinsdale D, Vermylen J, Hoylaerts MF, Nemery B. Diesel Exhaust Particles in Lung Acutely Enhance Experimental Peripheral Thrombosis. Circulation. 2003;107:1202-8.

32. Nurkiewicz TR, Porter DW, Barger M, Millecchia L, Rao KMK, Marvar PJ, et al. Systemic Microvascular Dysfunction and Inflammation after Pulmonary Particulate Matter Exposure. Environ Health Perspect. 2006;114(3):412-9.

33. Suzuki Y, Tada-Oikawa S, Ichihara G, Yabata M, Izuoka K, Suzuki M, Sakai K, Ichihara S. Zinc oxide nanoparticles induce migration and adhesion of monocytes to endothelial cells and accelerate foam cell formation. Toxicol Appl Pharmacol. 2014;278(1):16-25.

34. Paszek E, Czyz J, Woźnicka O, Jakubiak D, Wojnarowicz J, Łojkowski W, Stepieo E. Zinc oxide nanoparticles impair the integrity of human umbilical vein endothelial cell monolayer in vitro. J Biomed Nanotechnol. 2012;8(6):957-67.

35. Alfaro-Moreno E, Nawrot TS, Nemmar A, Rosas I, Schwarze P. Particulate Matter and Nanoparticles Toxicology. Biomed Res Int. 2013;2013:642974.

36. Stapleton PA, Minarchick VC, McCawley M, Knuckles TL, Nurkiewicz TR. Xenobiotic Particle Exposure and Microvascular Endpoints: A Call to Arms. Microcirculation. 2012;19(2):126-42.

37. Hasheminassab S, Daher N, Ostro BD, Constantinos S. Long-term source apportionment of ambient fine particulate matter (PM2.5) in the Los Angeles Basin: A focus on emissions reduction from vehicular sources. Environ Pollut. 2014;193:54-64.

38. Silva RM, TeeSy C, Franzi L, Weir A, Westerhoff P, Evans JE. Biological Response to Nano-Scale Titanium Dioxide (TiO2): Role of Particle Dose Shape, and Retention. J Toxicol Environ Health A. 2013;76(16):953-72.

39. Alfaro-Moreno E, López-Marure R, Montiel-Dávalos A, Symonds P, OsornioVargas AR, Rosas I, Clifford MJ. E-Selectin expression in human endothelial cells exposed to PM10: The role of endotoxin and insoluble fraction. Environ Res. 2007;103(2):221-8.

40. Montiel-Dávalos A, Alfaro-Moreno E, López-Marure R. PM2.5 and PM10 Induce the Expression of Adhesion Molecules and the Adhesion of Monocytic Cells to Human Umbilical Vein Endothelial Cells. Inhal Toxicol. 2007;19:91-8.
41. Montiel-Dávalos A, Ibarra-Sánchez MJ, Ventura-Gallegos JL, Alfaro-Moreno E, López-Marure R. Oxidative stress and apoptosis are induced in human endothelial cells exposed to urban particulate matter. Toxicol In Vitro. 2010; 24(19):135-41.

42. Sekuła M, Janawa G, Stankiewicz E, Stępień E. Endothelial microparticle formation in moderate concentrations of homocysteine and methionine in vitro. Cell Mol Biol Lett. 2011;16(1):69-78.

43. Perretti M, Ingegnoli F, Wheller SK, Blades MC, Solito E, Pitzalis C. Annexin 1 modulates monocyte-endothelial cell interaction in vitro and cell migration in vivo in the human SCID mouse transplantation model. J Immunol. 2002; 169(4):2085-92

44. Rui W, Guan L, Zhanga F, Zhang W, Ding W. PM2.5-induced oxidative stress increases adhesion molecules expression in human endothelial cells through the ERK/AKT/NF-kB-dependent pathway. J Appl Toxicol. 2015; doi: 10.1002/jat.3143.

45. Cerletti C, Tamburrelli C, Izzi B, Gianfagna F, de Gaetano G. Plateletleukocyte interactions in trombosis. Thromb Res. 2012;129(3):263-6.

46. Evangelista V, Manarini S, Sideri R, Rotondo S, Martelli N, Piccoli A, et al. Platelet/polymorfophonuclear leukocyte interacction: P-selectin triggers protein-tyrosine phosphorylation-dependent CD11b/CD18b adhesion: role of PSGL-1 as a signaling molecule. Blood. 1999;93(3):876-85.

47. Zapata E, Ventura JL, De la Cruz K, Rodriguez E, Damián P, Massó F, et al. Dehydroepiandrosterone inhibits the proliferation of human umbilical vein endothelial cells by enhancing the expression of p53 and p21, restricting the phosphorylation of retinoblastoma protein, and is androgen- and estrogen-receptor independent. FEBS J. 2005;272:1343-53.

\section{Submit your next manuscript to BioMed Central and we will help you at every step:}

- We accept pre-submission inquiries

- Our selector tool helps you to find the most relevant journal

- We provide round the clock customer support

- Convenient online submission

- Thorough peer review

- Inclusion in PubMed and all major indexing services

- Maximum visibility for your research

Submit your manuscript at www.biomedcentral.com/submit
BioMed Central 